Vol. 44, N. 2 : pp. 141 - 147, June, 2001

ISSN 1516-8913 Printed in Brazil

AN INTERNATIONAL JOURNAL

\title{
Biogenic Gases in Tropical Floodplain River
}

\author{
Maria Victória Ramos Ballester ${ }^{1^{*}}$ and José Eduardo dos Santos ${ }^{2}$ \\ ${ }^{1}$ CENA-USP. Av. Centenário, 303, 13416-000- Piracicaba - São Paulo - Brazil, ${ }^{2}$ Depto. de Hidrobiologia, \\ UFSCar.Via Washington Luiz, km 235, C.P. 676, 13565-905 - São Carlos - SP, Brazil
}

\begin{abstract}
Analysis of the distribution of biogenic gases in the floodplain of the Mogi-Guaçu River (São Paulo, Brazil) enabled the establishment of a "redox hierarchy", in which the main channel was the most oxidizing environment, followed by Diogo Lake, with Infernão Lake having the most reducing conditions of the subsystems evaluated. Diogo Lake

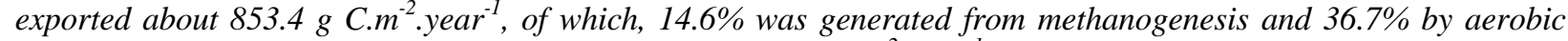
respiration. For Infernão Lake, these values were $2016 \mathrm{~g} \mathrm{C.m}^{-2}$.year ${ }^{-1}, 1.8 \%$ and $41.5 \%$, respectively. Carbon export by these systems was predominantly in the form of $\mathrm{CO}_{2}$, which was responsible for the release of $728.78 \mathrm{~g}$ C. $\mathrm{m}^{-2}$.year ${ }^{-1}$ at Diogo Lake and $1979.72 \mathrm{~g} \mathrm{C.m^{-2 } . \text { year }}{ }^{-1}$ at Infernão Lake. Such patterns may result from the nature of the hydrological conditions, the action of the hydroperiod, and morphological characteristics of the environment.
\end{abstract}

Key words: Biogenic gases; methanogenesis; aerobic respiration; $\mathrm{CO}_{2}$ production

\section{INTRODUCTION}

Floodplain rivers are considered important sources and/or sinks of many carbon species (Hedges et al., 1986). In these environments, rates of organic production are high and anoxic conditions are very frequent. Because of these characteristics, such rivers are regarded as important sources to the atmosphere of reduced gases; decomposition by methanogenic bacteria can be an important pathway of carbon remineralization and significant methane emissions to the atmosphere can take place (Crill et al., 1988; Devol et al., 1994). However, there is still little information about the terminal carbon processing in this type of wetland, considering especially the role of anaerobic processes (Pulliam, 1993), the regulatory mechanisms, and detailed seasonal variations in fluxes. Richey et al. (1988), analyzing the distribution of biogenic gases in a series of habitats in the Amazon river floodplain found that an oxi-reduction sequence could be established, ranging from oxidizing (high $\mathrm{O}_{2}$ and low $\mathrm{CO}_{2}$ and $\mathrm{CH}_{4}$ concentrations) to highly reducing (with high $\mathrm{CO}_{2}$ and $\mathrm{CH}_{4}$ levels and depletion of $\mathrm{O}_{2}$ ) environments, and that such distributions could be useful in understanding organic matter production and consumption in aquatic ecosystems. One of the most important factors controlling the biogeochemical and ecological characteristics in floodplain rivers is the hydroperiod (Lugo et al., 1990), which regulates primary production and decomposition processes, and the extent to which aerobic and anaerobic microbial processes take place. The main objective of the present study was to examine the carbon oxidation-reduction

\footnotetext{
* Author for correspondence
} 
processes using biogenic gases distribution analysis, as well as to evaluate the influence of the hydroperiod on the seasonal distributions.

\section{STUDY AREA}

Dissolved gases were determined in the main channel and in two oxbows lakes (Diogo and Infernão) of the Mogi-Guaçu river floodplain (Fig. 1). This area has been the object of many biogeochemical and ecological studies and detailed descriptions of the geographical, physical and ecological characteristics can be found elsewhere (Santos et al., 1995). The annual mean values of temperature and precipitation of the study area are $21.7^{\circ} \mathrm{C}$ and $1550 \mathrm{~mm}$, respectively. The year can be divided in two different periods: the wet season, with frequent rain and high temperatures (November to April) and the dry season, with lower amounts of rain and lower temperatures (May to October).

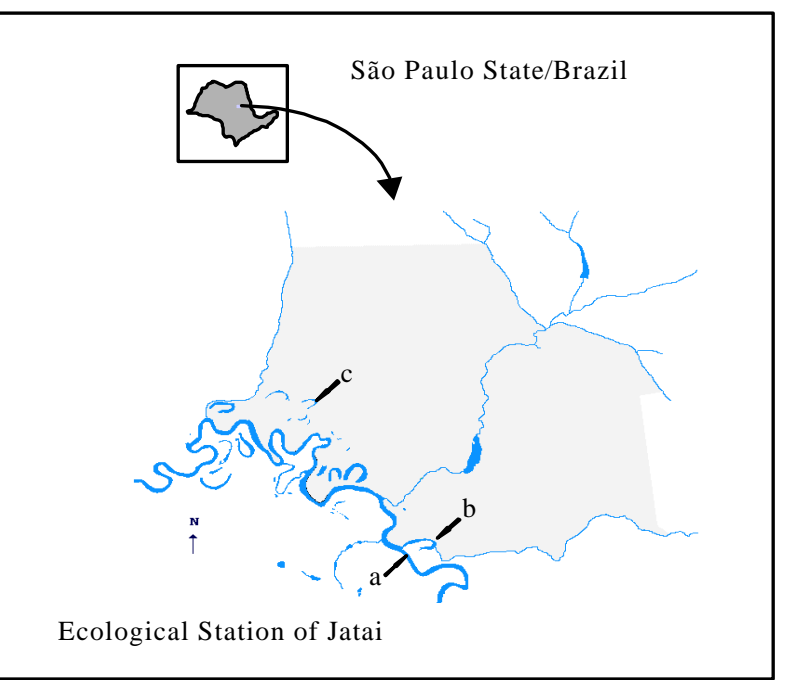

Figure1 - Localization of the Ecological Station of Jatai and sampling locations: a) main channel (Mogi-Guaçu River); b) Diogo Lake and c) Infernão Lake.

The Mogi-Guaçu River has a unimodal inundation regime, i.e., potential conditions of inundation only once a year, during the wet season (Krusche, 1989). The floodplain inundation occurs as pulses of rapid duration, ranging from ca 2 to 31 days. The water level of the lakes shows a simultaneous but not necessarily direct variation with the river discharge increase. Diogo Lake, a drainage system, has a permanent connection with the main river channel. Changes in the river discharge are reflected directly in the depth of the water column of the lake, which increases and decreases linearly as a function of the river level. Infernão Lake, a seepage system, is $600 \mathrm{~m}$ away from the main channel and only communicates with the latter through the floodplain during the wet season.

\section{METHODS}

Water samples were collected during one year, using a Van Dorn bottle (January 1991 to February 1992). In the river, samples were collected in the middle of the channel at the surface. In the lakes, surface and bottom $(0.5 \mathrm{~m}$ above the bottom sediment) samples were taken in two different habitats: open water and macrophyte beds, dominated by Eichhornia azurea, Panicum pernambucense and Scirpus cubensis. The Van Dorn bottle was subsampled for measurements of: $\mathrm{pH}$, water temperature, dissolved oxygen, total carbon dioxide $\left(\Sigma \mathrm{CO}_{2}\right)$ and dissolved methane. Dissolved oxygen content was determined by the Winkler method (Golterman et al., 1978) and $\Sigma \mathrm{CO}_{2}$ by conductivity in a Flow Injection Analysis system (Jardim \& Rohwedder, 1990). Concentrations of free dissolved $\mathrm{CO}_{2}$ were calculated from $\mathrm{pH}$ and $\Sigma \mathrm{CO}_{2}$ (Skirrow, 1975). Water samples for dissolved methane were analysed using the multiple fase equilibration method (McAuliffe, 1971) for gas extraction. Gas samples were returned to the laboratory, and after 12 hours, analyzed for $\mathrm{CH}_{4}$ in a flame ionization detection gas chromatograph, using the external standard method. Methane fluxes to the atmosphere were determined by changes in the concentrations of floating chambers (Ballester, 1994) placed over the water or vegetated surface. $\mathrm{CO}_{2}$ and $\mathrm{O}_{2}$ fluxes to the atmosphere were calculated using the boundary-layer model (Liss, 1973; Broecker \& Peng, 1974). Apparent Oxygen Utilization (A.O.U.) and Apparent $\mathrm{CO}_{2}$ Production $\left(\mathrm{CO}_{2}{ }^{*}\right)$ were calculated as proposed by Richey et al., 1988. Data are presented as means $\pm 1 \mathrm{SD}$ unless otherwise stated.

\section{RESULTS AND DISCUSSION}

The aquatic environments of the Mogi-Guaçu River floodplain were characterized by positive values of $\mathrm{CO}_{2}{ }^{*}$ and A.O.U. (Table 1), indicating an excess of respiration over photosynthesis. 
There was also a general association between high levels of $\mathrm{CO}_{2}{ }^{*}$, A.O.U. and $\mathrm{CH}_{4}$ (Fig. 2). However, in some of the macrophyte bed water samples of the lakes, negative values of A.O.U. were found. Dissolved methane was found in concentrations supersaturated with respect to the atmospheric equilibrium in all the habitats sampled. Higher levels were observed in the stagnant, anoxic bottom water of Infernão Lake, with concentrations up to 100 times higher than those observed in Diogo Lake and the main channel.
Main channel values of $\mathrm{CO}_{2}{ }^{*}$ were about 4 to 30 times greater, and dissolved oxygen content about $13 \%$ lower than the expected levels at atmospheric equilibrium. Methane concentrations (Table 1) were similar to those reported for tropical regions (Bartlett et al., 1990; Devol et al., 1994). These findings didn't necessarily mean that methane was produced in the main channel, where such generation was probably limited due to the sandy and well oxygenated characteristics

Table 1 - Means values ( $\pm 1 \mathrm{SD}$ ) of $\mathrm{CO}_{2}{ }^{*}$, A.O.U. and $\mathrm{CH}_{4}$

\begin{tabular}{lccc}
\hline Sampling Station & $\mathrm{CO}_{2} *\left(\mathrm{~mol}^{-1} \mathrm{~L}^{-1}\right)$ & A.O.U. $\left(\mathrm{mol} . \mathrm{L}^{-1}\right)$ & $\mathrm{CH}_{4}\left(\mathrm{~mol}^{\left.-\mathrm{L}^{-1}\right)}\right.$ \\
\hline Main Channel & $147.48( \pm 97.56)$ & $29.68( \pm 21.74)$ & $0.94( \pm 0.785)$ \\
Diogo Lake, Open Water, Surface & $174.91( \pm 25.2)$ & $61.77( \pm 10.62)$ & $0.73( \pm 0.51)$ \\
Diogo Lake, Open Water, Bottom & $263.65( \pm 35.8)$ & $135.04( \pm 11.98)$ & $1.35( \pm 0.71)$ \\
Diogo Lake, Macrophytes, Surface & $144.06( \pm 25.87)$ & $48.8( \pm 11.39)$ & $0.84( \pm 0.501)$ \\
Diogo Lake, Macrophytes, Bottom & $138.64( \pm 27.98)$ & $127.49( \pm 13.14)$ & $2.60( \pm 2.372)$ \\
Infernão Lake, Open Water, Surface & $453.25( \pm 25.72)$ & $178.88( \pm 5.4)$ & $7.40( \pm 8.103)$ \\
Infernão Lake, Open Water, Bottom & $720.03( \pm 96.74)$ & $224.4( \pm 6.66)$ & $166.45( \pm 151.31)$ \\
Infernão Lake, Macrophytes, Surface & $327.88( \pm 38.9)$ & $85.97( \pm 18.74)$ & $4.70( \pm 6.181)$ \\
Infernão Lake, Macrophytes, Bottom & $687.69( \pm 81.79)$ & $211.91( \pm 8.52)$ & $148.86( \pm 193.06)$ \\
\hline
\end{tabular}

SD : Standard Deviation

$\mathrm{CO}_{2}^{*}$ : Apparent $\mathrm{CO}_{2}$ Production

A.O.U. : Apparent Oxygen Utilization

of the sediments. As has been observed in similar systems (Pulliam, 1993; Richey et al., 1988), methane could be produced in the marginal zones or even on the floodplain. In the oxbows lakes, the lowest values for the dissolved gases were observed for Diogo Lake. Levels of $\mathrm{CO}_{2}{ }^{*}$ and A.O.U. in the open water were in general higher at the bottom. In the macrophyte bed, $\mathrm{CO}_{2} *$ had a varying seasonal distribution, with higher levels occurring alternatively at the surface and the bottom. $\mathrm{CH}_{4}$ concentrations were constant during the year in both sampling habitats, with slightly higher levels at the bottom. $\mathrm{CO}_{2}{ }^{*}$ and A.O.U. levels at Infernão Lake were higher than those observed in the other subsystems. For this lake, anoxic conditons were found at the bottom of both sampling habitats. Levels of dissolved oxygen higher than those expected at atmospheric equilibrium were found only at the surface of the macrophyte beds. For dissolved methane concentrations, there was a significant difference between wet and dry seasons, with higher levels during the former. The macrophyte bed showed a similar pattern.

The highest levels of A.O.U. and $\mathrm{CO}_{2} *$ for both lakes were observed during the wet season, although seasonal distributions differed. During this period, the organic matter contribution from surrounding areas in the form of detritus could have been responsible for the sharp decrease in the oxygen content and the increase of dissolved $\mathrm{CO}_{2}$. This pattern of greater $\mathrm{O}_{2}$ consumption and $\mathrm{CO}_{2}$ production observed during the rainy season could be the result of the increase in water column temperature and a higher availability of organic material. An additional factor influencing the observed reduction in aerobic conditions was an increase in the quantity of suspended material in the water column (Albuquerque \& Mozeto, 1997), which could be responsible for decreases in water transparency and primary production. At Infernão Lake, the more anoxic conditions and thermal stratification of the water column (Nogueira et al., 1996) could have been responsible for the methane accumulation in the hypolimnium. In lakes, the oxygen content of the water column was closely related to the processes of circulation and stratification; these processes seemed to be very different for the two lakes studied. The higher oxygen levels observed in Diogo Lake could have 
been the result of the constant supply of welloxygenated water coming from the Cafundó stream influencing mainly the bottom layers and the macrophyte bed, where the stream such generation was probably limited due to the mouth was situated. These results so expected since the Cafundó stream has been identified as an important determinant of the chemical composition of the lake, primarily during the dry
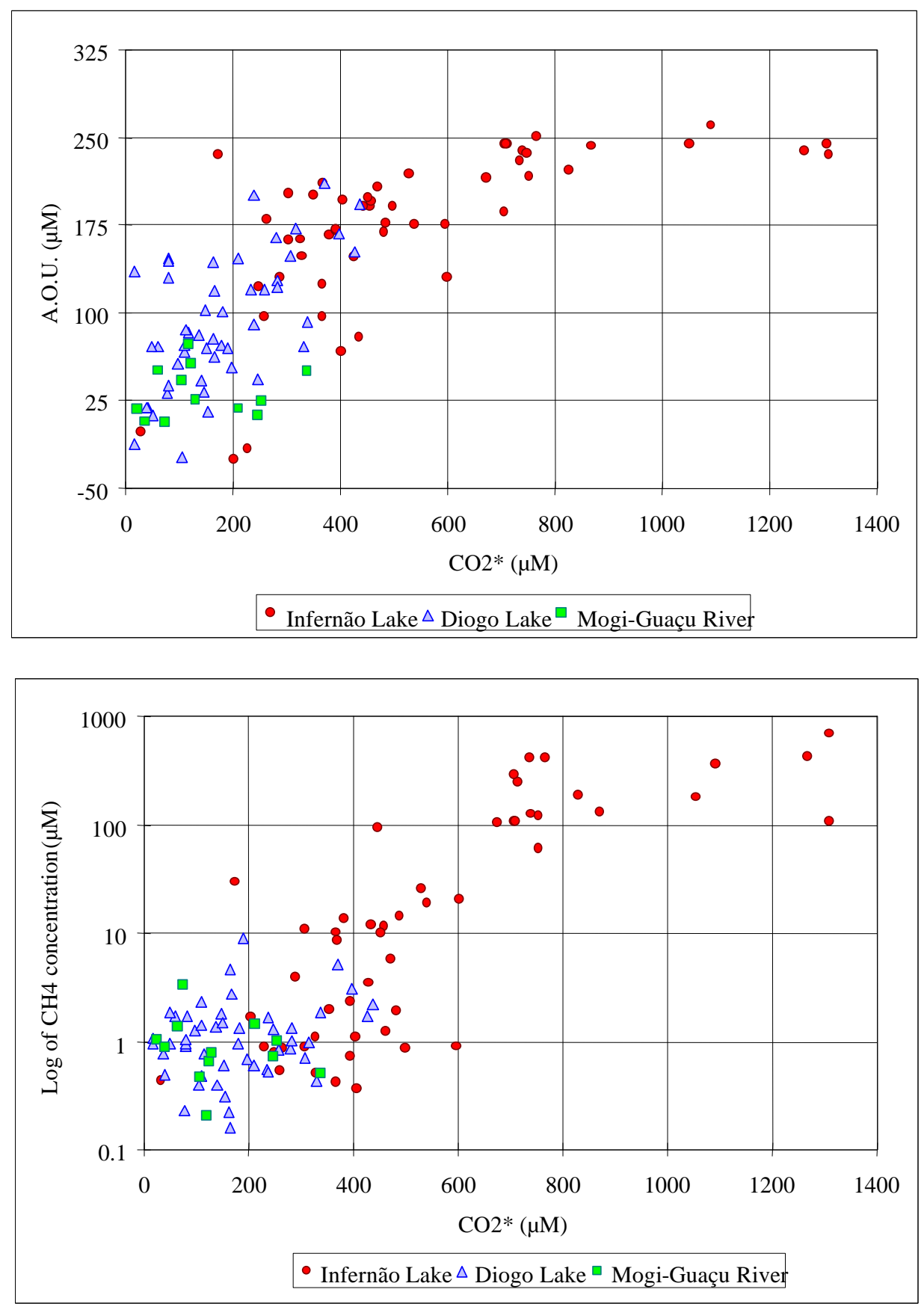

Figure 2 - A) $\mathrm{CO}_{2} *$ (Apparent $\mathrm{CO}_{2}$ Production) - A.O.U. (Apparent Oxygen Utilization) property-property plots. B) $\mathrm{CO}_{2} *$ (Apparent $\mathrm{CO}_{2}$ Production) - $\mathrm{CH}_{4}$ property-property plots

season (Krusche, 1989) and, therefore, could be responsible for the absence of anoxic conditions and methane accumulation in the hypolimnion. In addition, Diogo Lake can be regarded as an exposed system, more susceptible to wind action, leading to water column circulation, mainly during 
the dry season when the water level is very low $(\sim 1.5 \mathrm{~m})$. This kind of action seemed to be less strong at Infernão Lake, a more sheltered system which maintained a deeper water column $(\sim 3.5 \mathrm{~m})$ during the whole year. This fact, associated with the absence of a continuous input of running water richer in oxygen, could be responsible for the lower levels of oxygen in the latter lake. However, these lower values could also be an indication that more intense decomposition processes were taking place in this lake, where the respiratory rates were slightly higher (Ballester, 1994).

The fact that the $\mathrm{CO}_{2} *$ values exceeded the levels expected for atmospheric equilibrium could be the result of in situ organic matter oxidation (Martins \& Probst, 1991) resulting from a chain of aerobic and anaerobic respiration and fermentation processes (Nedwell, 1984), suggesting that the Mogi-Guaçu River floodplain could be a source of atmospheric $\mathrm{CO}_{2}$. Similar results of high values of dissolved $\mathrm{CO}_{2}$ have been reported for tropical lakes (Richey et al., 1991). In deeper zones, anoxic conditions are common and $\mathrm{CO}_{2}$ and $\mathrm{CH}_{4}$ accumulate (Devol et al., 1994); this was observed at Infernão Lake.

The flux of biogenic gases at the water-atmosphere interface can be used as an indicator of the contributions of aerobic and anaerobic decomposition processes in the carbon remineralization (Richey et al., 1988). Using this approach, and assuming that the sum of the fluxes of $\mathrm{CO}_{2}$ and $\mathrm{CH}_{4}\left(\mathrm{~F}_{\mathrm{C}}=\mathrm{F}_{\mathrm{CO} 2}+\mathrm{F}_{\mathrm{CH} 4}\right)$ represents the total decomposition of organic carbon, it could be calculated that Diogo Lake exports about 853.4 $\mathrm{gC} . \mathrm{m}^{-2}$.year ${ }^{-1}, \quad 14.6 \%$ generated from methanogenesis and $36.7 \%$ from aerobic respiration. For Infernão Lake, these values were 2016 gC. $\mathrm{m}^{-2}$.year ${ }^{-1}, 1.8 \%$ and $41.5 \%$, respectively. Carbon exportation as $\mathrm{CO}_{2}$ was responsible for the release of $728.78 \mathrm{gC} . \mathrm{m}^{-2}$.year ${ }^{-1}$ at Diogo Lake and $1979.72{\mathrm{gC} . \mathrm{m}^{-2} \text {.year }}^{-1}$ at Infernão Lake (Fig. 3). The methane contribution was in the same range of variation reported for similar wetlands (Pullian, 1993; Richey et al., 1988), with the Diogo Lake values being relatively high. Infernão Lake released about 2.4 times more carbon than Diogo Lake. Nevertheless, the contribution of aerobic respiration to the total carbon flux was almost the same $(\sim 40 \%)$ which suggested that other processes of anaerobic respiration and the microbial consumption of methane could be responsible for those differences.

The observed differences between the lakes in the role of methanogenesis in the total carbon flux to the atmosphere could be the result of differences in the intensity and relative importance of methane production, consumption and emission mechanisms, which seemed to occur at different rates in each lake. Oxbows lakes can be regarded as important potential sources of reduced gases to the atmosphere with a significant contribution of methane production to the carbon remineralization. The analysis of the distribution of biogenic gases in the Mogi-Guaçu River floodplain river has enabled the recognition of a "redox hierarchy" of the subsystems evaluated,

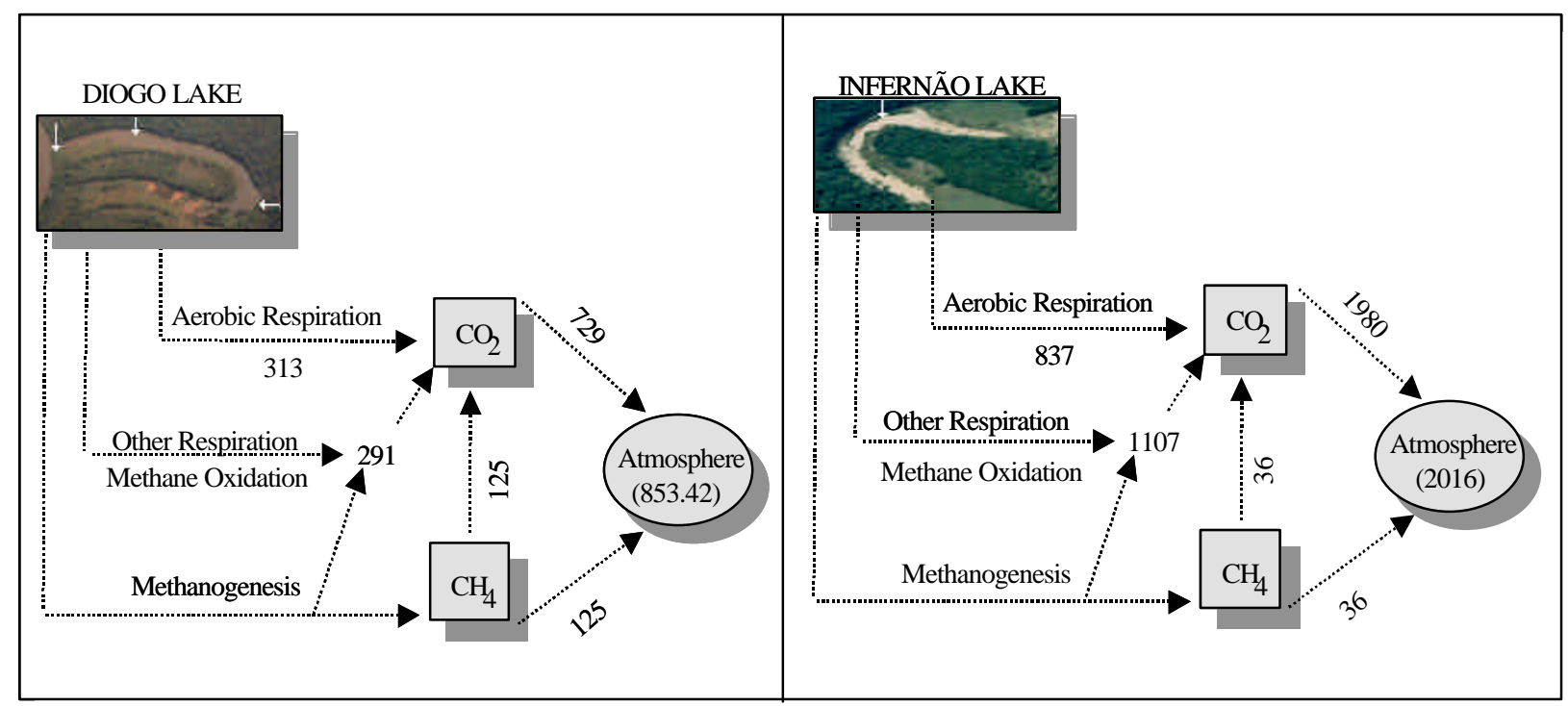

Figure 3 - Rates and pathways of terminal respiration at Diogo and Infernão Lakes. Numbers on arrows show estimated carbon fluxes in $\mathrm{g} \cdot \mathrm{m}^{-2}$.year ${ }^{-1}$. 
where the main channel is the most oxidizing environment, followed by Diogo Lake, with Infernão Lake having the most reducing conditions. This distribution pattern may be the result of the hydrological conditions and the diverse effects of the hydroperiod. For oxbows lakes, the position on the floodplain, as well as morphological characteristics are additional factors that must be considered.

\section{RESUMO}

A análise da distribuição de gases biogênicos na planície de inundação do Rio Mogi Guaçu (São Paulo, Brasil) possibilitou o estabelecimento de um gradiente redox para os sistemas aquáticos avaliados, em que o canal principal do rio apresentou-se como o ambiente mais oxidado, seguido da Lagoa do Diogo, e a Lagoa do Infernão apresentando as condições mais redutoras entre os ambientes em questão. A Lagoa do Diogo exporta um total de 853,4 g C.m ${ }^{-2}$.ano ${ }^{-1}$, do qual $14,6 \%$ é produzido pela metanogênese e $36,7 \%$ pela respiração aeróbia. Para a Lagoa do Infernão estes valores foram respectivamente de 2.016 g C.m ${ }^{2}$. ano $^{-1}, \quad 1,8 \%$ e de $41,5 \%$. A exportação de carbono por estes sistemas é realizada, predominantemente na forma de $\mathrm{CO}_{2}$, nos valores de 728,78 g C. $\mathrm{m}^{-2}$.ano ${ }^{-1}$ para a Lagoa do Diogo e $1.979,72 \mathrm{~g} \mathrm{C}^{-2} \mathrm{~m}^{-2}$ ano $^{-1}$ para a Lagoa do Infernão. Estes padrões parecem estar relacionados com a natureza das condições hidrológicas, com a ação do hidroperíodo e com as características morfológicas do ambiente.

\section{REFERENCES}

Albuquerque, A. L. S. and Mozeto, A. A. (1997), C : N : P Ratios and stable Carbon isotope compositions as indicators of organic matter sources in a riverine wetland system (Mogi-Guaçu River, São PauloBrazil). Wetlands, $17,1-9$

Ballester, M. V. R. (1994), Dynamic of biogenic gases $\left(\mathrm{CH}_{4}, \mathrm{CO}_{2}\right.$ and $\left.\mathrm{O}_{2}\right)$ in the Mogi-Guaçú River floodplain, Ecological Station of Jatai, SP. Ph.D. Thesis. Federal University of São Carlos, Brazil. . (In Portuguese)

Bartlett, K. B.; Crill, P. M.; Bonassi, J. A.; Richey, J. E. and Harris, R. C. (1990), Methane flux from the Amazon River floodplain: emissions during rising water. J. Geophys. Res., 95, 1773-1788
Broecker, W. S. and. Peng, T. H. (1974), Gas exchange rates between air and sea. Earth and Planetary Sci. Lett., 26, 21-35

Crill, P. M.; Bartlett, K. B; Wilson, J. O.; Sebacher, D. I. and Harris, R. C. (1988), Tropospheric methane from an Amazon floodplain lake. J. Geophys. Res., 93, 1564-1570

Devol, A. H.; Richey, J. E.; Forsberg, B. R. and Martinelli, L. A. (1994), Environmental methane in the Amazon River floodplain, In-Global Wetlands: old world and new, ed. W. J. Mitsch.. Elsevier Sci. 151-165

Golterman, H. L.; Clymo, R. S. and Ohnstad, M. A. M. (1978), Methods for physical and chemical analysis of fresh waters. I. B. P. Handbook 8. Blackwell Scientific Publ.

Hedges, J. I.; Clark, W. A.; Quay, P. D.; Richey, J. E.; Devol, A. H. and Santos, U. de M. (1986), Composition and fluxes of particulate organic material in the Amazon River. Limnol. Oceanogr., 31, 717-738

Jardim, W. F. and Rohwedder, J. J. R. (1990), Short-term toxicity test using Escherichia coli: monitoring $\mathrm{CO}_{2}$ production by flow injection analysis. Wat. Res., 24, 351-354

Krusche, A. V. (1989), Biogeochemical characterization of Diogo Lake, an oxbow lake of the Mogi-Guaú River floodplain. Ecological Station of Jatai, Luiz Antônio, SP. Ms.C. Dissertation. Federal University of São Carlos. (in Portuguese).

Liss, P. S. (1973), Processes of gas exchange across an air-water interface. Deep-Sea Res., 20, 221-238

Lugo, A. F.; Brown, S. and Brinson, M. M. (1990), Concepts in Wetland Ecology. In-Forested Wetlands. Ecosystems of the World 15, eds. A. E. Lugo; M. Brinson and S. Brown. Elsevier Sci., 171-184

Martins, O. and Probst, J. L. (1991), Biogeochemistry of major African river : carbon and mineral transport. In-Biogeochemistry of major world rivers. SCOPE 42, eds. E.T. Degens; S. Kempe and J. E. Richey. Wiley \& Sons, 127-156

McAullife, C. (1971), GC determination of solutes by multiple phase equilibration. Chem. Technol., 1, 46-51

Nedwell, D. B. (1984), The input and mineralization of organic carbon in anaerobic aquatic sediments. InAdvances in Microbial Ecology, ed. K.C. Marshall. N. Y. Plenum Press. New York , 93-131

Nogueira, F.; Esteves, F. A. and Prast, A. E. (1996), Nitrogen and phosphorus concentration of different structures of the aquatic macrophytes Eicchornia azurea Kunth and Scirpus cubensis Poepp \& Kunth in relation to water level variation in Lagoa do Infernão (São Paulo, Brazil). Hydrobiologia, 328 , 199-205

Pulliam, W. M. (1993), Carbon dioxide and methane exports from a southeastern floodplain swamp. Ecol. Monogr., 63, 29-53 
Richey, J. E.; Devol, A. H.; Wofsy, S. C.; Victoria, R. L. and Ribeiro, M. N. G. (1988), Biogenic gases and the oxidation and reduction of carbon in Amazon River and floodplain waters. Limnol. Oceanogr., 33, 551-561

Richey, J. E.; Victoria, R. L.; Salati, E. and Forsberg, B. R. (1991), The biogeochemistry of a major river system : The Amazon case study. InBiogeochemistry of major world rivers. SCOPE 42, ed. E. T. Degens; S. Kempe and J. E. Riche.. Wiley \& Sons. New York. 57-74
Santos, J. E.; Ballester, M. V. R.; Jesus, T. P.; Pires, J. S. R. and Obara, A. T. (1995), A systemic approach to management of natural areas. Study case : Jatai Ecological Station, Luiz Antonio.

SP. Oecologia Brasiliensis, I, 487-502. (in Portuguese). Skirrow, G. (1975), The dissolved gases - carbon dioxide. In-Chemical Oceanography, eds. J.P. Reley and G. Skirrow. London Academic Press Inc. London. pp. 227-322 